\title{
Demography Bonus and Policy Projection for Riau Province Youth Development
}

\author{
Bahjatul Murtasidin \\ Department of Government Studies \\ University of Abdurrab \\ Pekanbaru, Indonesia \\ bahjatul.murtasidin@univrab.ac.id
}

\author{
Seri Hartati \\ Department of Government Studies \\ University of Abdurrab \\ Pekanbaru, Indonesia \\ seri.hartati@univrab.ac.id
}

\begin{abstract}
Indonesia is one of the countries which are undergoing a democracy and demographic transition process. The transition peak is expected to occur in 2020 until 2039 with productive age population is twice compared to non-productive population through all provinces in Indonesia, not least Riau Province. This condition is called as demographic bonus and not all countries in the world experience demographic bonus. This condition must be utilized as a momentum to reach the peak of the nation's progress, because this condition is also potential as a threat and disaster for Indonesian development existence,not least Riau Province. Therefore, this research is necessary for it aims to find the formulation of youth development policy in Riau Province in order to utilize the demographic bonus. The research uses qualitative research methods. The result of this research are: first, Youth Strategic Plans (Rencana Strategis Kepemudaan) as policy guide which have to be sharpened and adjusted with projection of demographic bonus. Second, Riau Province must prioritize "Youth Mainstreaming" as one of major programs. Third, Riau Province must develop "Youth Visionary-Services". Fourth, the article produce "Index of Youth Development". Fifth, Riau Province must activate youth participation. These five findings above are important to be done by the Local Government of Riau Province, especially for Youth and Sports Department as the leading sector of youth development in Riau Province to take advantage of the demographic bonus as the momentum of the resurrection, not vice versa for Riau Province Youth Development.
\end{abstract}

Keywords: Demographic Bonus, Youth Development, Riau Province.

\section{INTRODUCTION}

This paper aimed to have the formulation of youth development policy in Riau Province in order to take advantage of demographic bonus that is expected to occur in the year 2020-2039. The demographic bonus is defined as a condition of composition or structure population which have many advantages in terms of development, because the population of productive age is very large. In case the proportion of unproductive people is getting smaller and less, this condition is certainly very profitable and should be utilized as well as possible. The problem is, how can the Riau provincial government take advantage of demographic bonus opportunities?. Demographic bonus opportunities would be a demographic disaster considering the current data released by the Central Bureau of Statistics of Riau Province shows that the quality of human resources of the people of Riau is still quite low. Therefore, it is necessary the Riau Provincial Government prepare the right policy formulation in facing demographic bonus.

Riau is one of the provinces located strategically because it faces directly with the Malacca Strait which is one of the busiest straits in trading activities. In addition, Riau Province is also directly adjacent to Singapore and Malaysia. Strategically, the geographical location of Riau Province is on one side very advantageous, and on the other side many productive age cannot be a productive people in population and its become a threat for Riau Province. Therefore, it is necessary to improve the quality of human resources, especially among youths categorized as productive age population.

Leading sector of Human Resource quality improvement among Riau Province youth in facing demographic bonus is home work for Youth and Sports Department. This is in accordance with Regional Regulation Riau Province No. 2 of 2014 About the Organization of Regional Office of Riau Province. As an extension of the Riau Provincial Government, great hope is placed on the Youth and Sports Agency to be able to carry out its duties and obligations to improve the quality of youth development. Youth development is an inseparable link from the whole human development target and the whole Riau society.

The successful development of youth as a qualified human resource and competitive advantage is one of the keys to open opportunities for success in other development sectors. Therefore youth development is considered as one of the programs that can not be ignored in the face of demographic bonuses.

Preparing the efforts, building and empowering youth in a tiered and sustainable manner in order to be able to participate as active actors of development in Riau Province become the joint responsibility, and especially to the Government of Riau Province through the Organization of the Region which handles by Youth Affairs. The vision that has been set to realize the goal of youth development in Riau Province is "The Realization of Youth and Society of Healthy Sports, Religious, Malay Culture, National Concept, Mandiri 
and High Competitive Towards Vision of Riau Province 2020" [1].

\section{MATERIALS AND METHODS}

This research was conducted in Riau Youth and Sports Department. This agency is an extension of the Riau Province government that has responsibilities in the field of youth and sports services. This research used qualitative method with primary and secondary data as the source. Primary data was obtained directly from informant research with interview technique. It aims to find out firsthand how the policies that have been formulated by the Government of Riau Province through the Office of Youth and Sports. While the secondary data obtained by author from the documentation, mass media or information from other sources that can support the object under investigation. The data that have been obtained then analyzed by descriptive analysis.

\section{RESULTS AND DISCUSSION}

In the demographic study, Indonesia was predicted to get demographic bonus. This was reinforced by the results of population census In 2010, the number of Indonesian population reached 238.5 million people. Then in 2014 the Government of Indonesia launched the projection of the Indonesian population up to 2035 , estimated to increase to 305.6 million inhabitants or an increase of $28.14 \%$ from the calculation of 2010 [2]. Meanwhile, the Central Bureau of Statistics also released projected population based on the province in Indonesia, and Riau Province was projected to continue to increase population. In 2010 the population of Riau Province amounted to 5,574,900 people, and by the year 2035 is projected to number $9,363,000$ inhabitants.

This increasing number of inhabitants is a necessity that Indonesia in general and Riau in particular experienced a demographic transition. To see this demographic transition phase, the population is divided into three major groups. First, the younger age group, ie those under the age of 15 years $(0$ 14). Secondly, productive age group, that is population which enter in age category 15 until 64 year. Third, the elderly, those 65 years and over [3]. The basic assumption to understand demographic bonus was the condition of the composition of the productive age population was greater than the population of young and old age. Therefore, Indonesia until 2035 was predicted to experience demographic bonus.

\section{a. Demography Bonus and Implementation of Youth Development Policy in Riau Province}

Youth development in Riau Province refers to the grand design of youth development established by the Ministry of Youth and Sports of the Republic of Indonesia. Youth development policies implemented should be able to realize the youth who character, capacity, and competitive. This is a pillar that must be considered and gained the full attention of policy makers. Especially if faced with demographic bonus. Youth development should be directed to prepare cadres of the nation that are very potential for development and utilization of human resource productivity. This reminds us that the monumental work of a nation is its ability to produce superior and competitive youth human resources. Therefore, efforts are needed to bring the monumental work of a nation through the development of youth.

The demographic bonus was the right moment to realize this monumental work. Efforts to prepare and empower youth to be able to participate as active actors of development in the future in facing demographic bonus in Riau Province become joint responsibility, and especially for Riau Provincial Government through Youth and Sports Agency. Based on the drafted Strategic Plan, the program of activities to be implemented by the Office of Youth and Sports of Riau Province, among others:

First, the Youth Policy Development and Harmony Program includes: Expansion of Local Action Planning for Youth Sector, Preparation of Youth Profile, Youth Employment Technical Meeting, and Preparation of Local Regulation on Youth.

Second, the Program for Increasing the Role of Youth, includes: Expansion and Quality Improvement of Youth Organization of Rural Development Drivers in Riau Province, Youth Organization Development, Leadership Education and Training, Youth Organization Speech Meeting Facilities, Selection of Flag and Provincial Flags, Training and Implementation of Flag Flags on the Independence Day of the Republic of Indonesia, Jamboree and Bhakti Youth between Regencies / Provinces of Riau Province, Selection of Candidates for Intergovernmental Youth Exchange, Selection of Candidate Candidates for Youth Vessels, Selection of Pioneer Youth at Riau and National Provincial Levels, Organizing and Warning Youth Pledge Day, National Youth Resilience Training, Improved Competence of Flag Trainers, Management Training and Leadership Training for Youth Organization Organizers, Youth Development for Rural Development Drivers, Youth Leadership Training, Peer Scout Training duli, Indonesian Volunteer Facilitator / Training Facilitator in Riau Province, and Da'i and Da'iyah Training.

Third, Increased Entrepreneurship. Entrepreneurship and Youth Life Entrepreneurship Development Program includes Youth Entrepreneurship Training, Young Entrepreneurship Development and Development, and Development of Local Superior Crafts for Youth in Riau Province.

Fourth, Drug Abuse Prevention Program, including Socialization and Counseling Dangers of HIV / AIDS Drugs for Youth.From all the above mentioned activity programs, the authors' findings on the output of activities that have been implemented conclude that the Riau Provincial Government through the Youth and Sports Agency is not maximized in preparing its young generation to face the demographic bonus. This is indicated by several indicators that the authors pour into the formulation of youth development policy.

\section{b. Formulation of Youth Development Policy in Riau Province}

Riau Provincial Government has authorized the Youth and Sports Department as the leading sector of youth 
development, in demand to be more active in improving and renewing the needs and demands of youth as a foundation in facing demographic bonus. The formulation of youth development policy as follows:

1. Youth Strategic Plans as policy guide which have to be sharpened

Strategic plans are important in an organization. Because he gives a picture of the ideals to be achieved. The vision and mission description of the Youth and Sports Agency is contained in the document of the strategic plan. In the strategic plan 2014-2019, the Office of Youth and Sports has set a vision that is the Realization of Youth and Healthy Sports Community, Religion, Malay Culture, Respected Nationality, Mandiri and High Competitiveness Towards Vision Riau Province 2020. This strategic plan is comprehensive in describing the map youth. However, this strategic plan is not supported by the development strategy through the youth development architecture, either the architecture set by the youth and sports ministry, or the youth development architecture set by the relevant agencies. In addition, strategic plans are quite blunt in terms of policy execution. without describing policy directions and strategies, as well as the priority formula of the program.

\section{Youth Mainstreaming}

One of the important findings of the author is the lack of youth participation in planning, monitoring and evaluation of all policies and programs of activities. The culture built by the related agencies only involves the youth in the implementation stage of the activity. In fact, ideally, mainstreaming of youth through the promotion of youth participation, attention and involvement of youth in planning, implementation, monitoring and evaluation of all policies and programs in various areas of life and development [4]. Or in other words, mainstreaming of youth is basically the awareness and willingness of policy makers to pay attention to the needs of youth development programs. Mainstreaming of youth can be done well if supported by agencies that have awareness, willingness, and commitment. Important agencies are a matter of concern as each agency often gets stuck at the point of view of their respective institutions so as to require ongoing cross-sectoral communication and coordination.

\section{Youth Visionary-Services}

Bureaucracy reform is not easy. There is a complexity associated with each other. Structural and administrative improvement efforts should continue. Especially the development of youth is an immaterial thing, a concept that continues to move and change. Therefore, the Youth and Sports Department should be more sensitive and responsive to signs and phenomena. Youth visionary services give youth confidence, reward freedom, and openness to criticism.

\section{Youth Development Index}

The complexity of growth and youth problems in Riau Province clearly requires special handling, and this is not easy. Handling youth issues can not be separated from the complexity of their growth. The problem is the extent to which growth is the focus of government attention, because in fact the government itself does not have an instrument to measure the development of youth each year. The instrument model is the Youth Development Index. The Youth Development Index has the following functions: measuring youth development over time, identifying areas requiring further attention, comparing progress among provinces / regions, the basis for policy formulation, and encouraging the collection of data related to youth [5].

Through the Youth Development Index the government can get an overview of the factors that influence youth growth and development, making it easier for policy makers to formulate youth programs. In addition, there will be an analytical frame that maps and understands the existence of youth. The important thing to do by the government in formulating the right policy facing demographic bonus.

\section{Activate Youth Participation}

The absence of involvement and youth participation in development programs has become an issue not only in Riau but also a national issue. Although there is a musrenbang involving the representation of youth, often only a formality and dull in follow-up. And even then only in the planning stage. While at the implementation stage, monitoring and evaluation of the government have not been transparent enough in opening and attracting youth involvement. As far as the involvement of youth is limited to the participation and target of the beneficiaries. In fact, there is often a gap between program form and youth needs. If this condition continues, how can the government be able to use the young generation as a skilled man facing demographic bonus?

\section{CONCLUSION}

The efforts to perpare the youth in participating as active development actors in the future and also facing demographic bonus in Riau Provinc, its become the responsibility of Riau Provincial Government through Youth and Sports Agency. If the government is not sensible preparing policy formulations, the potential for demographic bonuses will turn into a demographic disaster. The established formulation must be well targeted and have clear and measurable outputs for the benefit of demographic bonus utilization. There are five important findings of the formulation of youth development policy in Riau Province, including: first, Youth Strategic Plans as policy guide which has to be sharpened and adjusted with projection of demographic bonus. Second, Riau Province must prioritize "Youth Mainstreaming" as one of major programs. Third, Riau Province must develop "Youth Visionary-Services". Fourth, the article produce "Index of Youth Development". Fifth, Riau Province must activate youth participation. These five findings above are important to be done by the Local Government of Riau Province, especially for Youth and Sports Department as the leading sector of youth development in Riau Province to take advantage of the demographic bonus as 
the momentum of the resurrection for Youth Development in riau Province.

\section{ACKNOWLEDGMENT}

This study received full support from the University of Abdurrab. Acknowledgments also the author conveyed to the Gorvernment of Riau Province through the Youth and Sports Department which was very helpful for the authors complete this research. Data and information are also meaningfull for writers.

\section{REFERENCES}

[1] Rencana Strategis (Renstra) Dinas Kepemudaan dan Olahraga Provinsi Riau Tahun 2014-2018

[2] Proyeksi Penduduk Indonesia 2010-2035. Jakarta: Badan Pusat Statistik (BPS), 2013

[3] Heryanah. Ageing Population dan Bonus Demografi Kedua di Indonesia. Badan Pusat Statistik: Sukabumi, 2015

[4] Susilo, Dwi Agus. Pemuda dan Pembangunan. Lembaga Jangka Indonesia: Jakarta, 2015

[5] Musthopa, Arif. Rekomendasi dan Siasat : Kemenpora dan Pemuda Menuju Revolusi Mental. Asisten Deputi Bidang Organisasi Kepemudaan Deputi Bidang Pemberdayaan Pemuda Kementerian Pemuda dan Olahraga, Jakarta, 2014. 